International Journal of Current Microbiology and Applied Sciences

ISSN: 2319-7706 Volume 6 Number 8 (2017) pp. 25-37

Journal homepage: http://www.ijcmas.com

Original Research Article

https://doi.org/10.20546/ijcmas.2017.608.005

\title{
Isolation, Identification and Characterization of Arbuscular Mycorrhizal Fungi in Apple (Malus domestica Borkh) Growing Area of Kashmir Himalaya
}

\author{
Misbah Ajaz , Mohammad Yousuf Zargar and Jagana Chandra Sekhar
}

Division of Basic Sciences and Humanities, Sher e Kashmir University of Agricultural Sciences and Technology of Kashmir-193201, J \& K, India

*Corresponding author

\section{A B S T R A C T}

Samples from rhizospheric soil and root pieces collected from 10 villages

Keywords

Isolation, Fungi,

Apple, Kashmir,

Himalaya

Article Info

Accepted:

04 June 2017

Available Online:

10 August 2017 of district Pulwama of Kashmir Himalaya were processed for isolation of arbuscular mycorrhizal spores and for their identification with the help of INVAM. The isolated genera were identified as Acaulospora, Scutellospora, Gigaspora, and Glomus. Glomus spores were more predominant while as Scutellospora spores were least predominant in the district. Spores of Gigaspora were larger in diameter than others. Glomus $s p$. showed higher root colonization from sunsomil, Acaulospora sp. from Pinglin, Gigaspora sp. from Shiekhar and Scutellospora sp. from Drubgam. Highest spore population and phosphatase activity was recorded in Pinglin. The highest biological activity was due to adequate application of organic manures in the soil and also due to application of fertilizers.

\section{Introduction}

Apple (Malus domestica Borkh.) is a premier table fruit, rich in nutrients especially fats, carbohydrates, calcium, phosphorus and iron. It is cultivated in temperate regions of the world and, to some extent, in cool highlands of some sub-tropical regions such as East Africa, Northern parts of India etc. India in terms of apple fruit production ranks fourth in the world. In India, apple cultivation alone accounts for 55 per cent of the total area and 75 per cent of the total production under temperate fruits in the country (Chadha, 1993). Commercial cultivation of apple fruit in India is confined to the States of Jammu and Kashmir and Himachal Pradesh, and some selected areas of Uttrakhand, Arunachal Pradesh, Manipur and Sikkim. In Jammu and Kashmir apple is grown on an area of 1.07 lakh ha with annual production of 12.08 lakh metric tonnes, which constitutes about 84 per cent of total fruit production in the State (Malik et al., 2016). In Horticulture sector the largest area of $43.53 \%$ is occupied by apple out of total area under fruit and $65.46 \%$ out of fresh fruit area (Anonymous, 2016) thereby making it the largest contributor to the state GDP among the horticulture produce.

District Pulwama is an important part of Kashmir valley with respect to the 
agricultural perspective and is surrounded by Srinagar in the north, Budgam and Poonch in the west and Anantnag and Shopian in the east and south side. The district is situated between $33^{\circ} 46^{\prime}$ to $33^{\circ} 58^{\prime} \mathrm{N}$ Latitude and $74^{\circ} 45^{\prime}$ to $75^{\circ} 13^{\prime} \mathrm{E}$ longitude with a mean elevation of about $1630 \mathrm{~m}$ amsl. It contributes a total geographical area of $0.109 \mathrm{~m}$ ha out of which $0.02365 \mathrm{~m}$ ha is under agriculture and $0.0412 \mathrm{~m}$ ha under forest cover, rest being used for other purposes. Pulwama soils are shallow to deep, mostly loam to silty loam and silty clay to clay. The wide variations in soil characteristics are mostly associated with slope aspect. The soils are mostly subjected to moderate to severe erosion and have moderate surface stoniness at some places.

The natural vegetation of the district consists of trees like Salix Alba, Populus Alba. The high hill ranges are covered with forests and dominant species are Pinus sylvestris, Pinus walichiana, Robinia pseudoacacia, Cedrus deodara, Abies pindrow and Picea smithiana. Several shrubs and herbs of medicinal value are also found in the forest. Agriculture is the main occupation of the people in the districts. Paddy, oil-seeds, fodder, saffron are the main agricultural crops of istrict Pulwama and fruits especially apple is the main horticultural crop of District. Pulwama is also known for both quantity and best quality apple in the valley.

Arbuscular mycorrhizal fungi play an important role in sustainable agriculture as well as agricultural ecosystem management. The important genera of endomycorrhizal fungi reported so far are Acaulospora, Entrophosphora, Gigaspora, Glomus, Sclerocystis and Scutellospora (Morton, 1988). All these fungi are obligatory associated with plant roots and develop symbiotic relationship with their hosts. Different species can be differentiated on the basis of sporocarp size, spore dimension, presence/absence of hyphal mantles, spore ornamentation (warts, wrinkles, pits, reticulum, spines etc.), spore walls, spore content, hyphal attachment, manner of spore germination, histochemical reaction etc. (Schenck et al.,1982). Keeping in view the importance of arbuscular mycorrhizal fungi in phosphorus solubization and very little work having been done on arbuscular mycorrhizae with respect to apple, the present investigation was taken up with the objective of isolation and purification of arbuscular mycorrhizal spores from the rhizospheric soil of apple, morphological characterization of the spores upto generic level and their root colonization studies.

Microbial enzymes constitute an important part of soil matrix as the extracellular enzymes, influencing soil microbial activity, exert control over soil enzymes production, control nutrient availability and soil fertility. Soil enzymes play key biochemical function in overall processes of organic matter decomposition in soil. Soil enzymes are significant in catalyzing several important reactions necessary for life process of an organism in soil, stabilizing soil structure, decomposition of organic wastes, organic matter formation and nutrient cycling. The enzyme activity has been reported to be important in determination of soil quality (Makoi and Nolakidema, 2008). These soil enzymes have also been suggested as potential indicator of soil health because of their essential role in soil biology (Riffaldi et $a l ., 2002)$

Phosphatases have been extensively studied in soil because they catalyze the hydrolysis of ester-phosphate bonds, leading to the release of phosphate, which can be taken up by plants or microorganisms. It has been shown that the activities of phosphatases (like those of many hydrolases) depend on several factors such as soil properties, soil organism interactions, 
plant cover, leachate inputs and the presence of inhibitors and activators. Phosphatases are enzymes catalyzing the hydrolysis of both esters and anhydrides of phosphoric acid.

\section{Materials and Methods}

\section{Study area}

Pulwama with geographic coordinates of $33.87162^{\circ} \mathrm{N}, 74.8946^{\circ} \mathrm{E}$ is one of the major apple growing district of Jammu and Kashmir with apple production 1, 39, 2, 88 MT in the year 2016-17 and the land under apple cultivation is $14290 \mathrm{H}$.

Ten villages (Rajpora, Shadimarg, Nikas, Drubgam, shiekhar, Tikkin, Sunsomil, Pinglin, Gungoo, Puhoo) were selected from district Pulwama. From each village three orchards were randomly chosen and from each orchard five rhizosphere soil samples were drawn which were composited into one representative sample. Most of the orchardists followed the pesticide schedule as per Department of Horticulture, Government of Jammu and Kashmir.

\section{Collection of root and soil samples}

Extensive field survey was carried out in order to collect the root and rhizospheric soils samples of three years old apple trees (var. Red delicious) from ten Villages of district Pulwama in June 2014-15.

Samples were collected randomly from the feeder roots on all sides of the canopy of the tree (fruiting stage). Rhizospheric soils at a depth of 0-30 cm from 5 different locations in each study site were collected in sterile polyethylene bags using soil auger.

A portion of the soil samples was analyzed for soil chemical parameters like soil organic carbon, available phosphorus, available potassium and available sulphur as per standard methods (Walkley and Black, 1934; Olsen, 1954; Stanford and English, 1949; Chesnin and Yien, 1951). Soil used during the present study contained $1.74 \%$ organic carbon, $357.43 \mathrm{~kg} / \mathrm{ha}$ available nitrogen, $17.05 \mathrm{~kg} / \mathrm{ha}$ phosphorus, $12.02 \mathrm{~kg} / \mathrm{ha}$ available sulphur and $185.38 \mathrm{~kg} / \mathrm{ha}$ available potassium and all these were in medium range.

Remaining soil samples of $200 \mathrm{~g}$ was used to isolate AM fungal spores. The root samples were washed thoroughly with running tap water to remove the adhered soil particles. Then roots were cut into small pieces of about $1 \mathrm{~cm}$ and fixed in Std. FAA solution until it is used for the assessment of \% colonization of AMF.

\section{Isolation and identification of arbuscular mycorrhizal fungal spores}

Isolation of $\mathrm{AM}$ fungal spores from the rhizospheric soil samples was done by following Wetsieving and decanting method (Gerdemann and Nicolson, 1963). The spores were counted under microscope Olympus $\mathrm{CH} 20 \mathrm{i}$ with magnification of $10 \times 40$.).

Spore population was then expressed in terms of number of spores per 100 gm of dry soil. Clean and intact spores were isolated using a specially designed needle, spores were mounted with PVLG (poly vinyl alcohol+ lactic acid+ glycerol) + Melzer's Reagent and observed under microscope and photographed.

Identification of spores up to generic level was based on spore size, spore colour, wall layers and hyphal attachments using the species descriptions provided by INVAM (http://invam.caf.wvu.edu) (INVAM， 2005) and other suitable references(Schenck et al.,1990; Morton and Benny,1990; Almeida 
and Schenck, 1990; Bentivenga and Morton,1995; Walker and Vestberg, 1998).

\section{Assessment of AM fungal colonization of isolated spores}

The isolated spores were further purified and mass multiplied on maize. Surface sterilized healthy maize seeds, pre-germinated in Petri plates under aseptic conditions, were sown in polythene bags containing sterilized soil + sand mixture $(1: 2 \mathrm{w} / \mathrm{w})$. These bags were aseptically inoculated with identical AM spores at $5 \mathrm{~cm}$ depth (Jackson, 1973). The bags were kept in a greenhouse at $25 \pm 3{ }^{\circ} \mathrm{C}$ and irrigated with sterile water. The plants were uprooted after 45 days.

The roots were collected, washed with sterile water to remove adhering soil debris and observed for mycorrhizal infection. The infectivity was proved by noticing the presence of hartig net, vesicles, asbuscules or hyphae of endophytes on roots.

For estimating mycorrhizal root colonization, the root samples were collected and washed carefully to remove the adhering debris. The tertiary roots were cut into small pieces of approximately $1 \mathrm{~cm}$ length and subjected to differential staining (Phillips and Hayman, 1970)

The estimation of mycorrhizal infection in roots was made by visual observation (Giovannetti and Mosse, 1980). A randomly selected aliquot of stained root segments, suspended in water, was spread in a Petridish viewed under a dissecting microscope at a magnification of 10 and $40 \times$. In case of AM colonization, root segments containing vesicles and arbuscules of endophyte and number of mycorrhizal short roots were considered infected (Beckjord, 1984).

Per cent mycorrhizal infection $=$ Number of infected root segments / Total number of segments examined $\times 100$

The data recorded during the investigation was statistically analyzed with the help of Pearson correlation (Gomez and Gomez, 1984).

\section{Results and Discussion}

\section{Morphological characterization of arbuscular mycorrhizal spores}

Spore morphology and wall characteristics were considered for the identification of arbuscular mycorrhizal fungi. Four types of genera viz., Glomus, Acaulospora, Scutellospora and Gigaspora, were recovered and identified. 3 to 6 unidentified spores per gram from all studied locations were tagged as unidentified spores (Table 1).

The spore colour of the species of Glomus was of wide range. It varied from red-brown to almost black or straw to dark orange but most was yellow brown in colour. Spores possessed globose to sub-globose shape, about 40 to $120 \mu \mathrm{m}$ in size.

Spore wall consisted of three layers (L1, L2 and L3). Our findings corroborate with those of many other workers (Koske, 1984; Koske and Gemma, 1990). Acaulospora spores were present singly in the soil and develop laterally on the neck of asporiferous saccule. Spores were light orange to yellowish brown (Table 2 and Figures 1, 2, 3 and 4) globose to subglobose in shape and 150 to $210 \mu \mathrm{m}$ in diameter.

These spores were triple layered with L1 which forms the spore surface light yellow to apricot yellow in colour and 0.7 to $2.0 \mu \mathrm{m}$ in thickness. L2 was laminate and light orange to yellowish brown, 6.8 to $7.4 \mu \mathrm{m}$ in thickness. L3 was laminate, hyaline, 0.8 to 1.6 $\mu \mathrm{m}$ in thickness and usually tightly adherent to L2. Similar observations have been reported by others also (Walker, 2007; 
Sharma, 2009). Scutellospora spores were with or without ornamentations. Spores consisted of a bilayered spore wall and two bilayered flexible inner walls.

Thin-walled auxillary cells with smooth to knobby surfaces were produced on hyphae in the soil near the root surface and were also reported by Morton (2002).

Gigaspora spore wall consisted of a permanent outer layer enclosing a laminate layer, each with different properties that distinguish species (e.g. color, thickness, etc). Our observations corroborate with those of Koske (1987) and Bentivenga et al., (1995).

There was no evidence of any ectomycorrhizal association with apple roots, and this corroborates with the findings of ${ }^{[29]}$. Glomus species was common and made up for more than $75 \%$ of total isolates followed by Acaulospora, Gigaspora and Scutellospora.

Dominancy of Glomus in the present study is in agreement with the findings of many other workers (Mridha and Dhar, 2007; Burni, 2009; Sharma, 2009). The predominance of Glomus spp. under varying soil conditions might be due to the fact that they are widely adaptable to the varied soil conditions and survive in acidic as well as in alkaline soils (Pande and Tarafdar,2004).
Root colonization studies of arbuscular mycorrhizal fungi

In the current study, the AM colonization in the apple roots from Pulwama district varied between 65.87 and $79.78 \%$ (Table 3, Figures $5,6,7$, and 8). The results are in conformity with the Kandula et al., (2006) who also observed higher colonization in the apple roots and confirmed the ubiquitous nature of AMF spores. The highest root colonization was recorded in response to the inoculation with Glomus spp. (79.78\%) followed by Acaulospora species (79.56\%), Gigaspora species $(73.56 \%)$ and Scutellospora species $(71.23 \%)$. Similar results were reported by some workers (Gosal et al., 2003; Smith and Read, 2008).Results of the present study indicate that the nutrient contents of the soils played a significant role in occurrence of different species of arbuscular mycorrhizal fungi and it is evident from the Perusal of the data presented in table 2 which revealed that AM spore population of district Pulwama was positively and significantly correlated with organic carbon $\left(\mathrm{r}=0.887^{* *}\right)$. The results are in conformity with those of (Lipinski et al., 2003) who also reported a significant positive correlation between soil organic carbon and AM spore population. There was a significant correlation between AM spore population and root colonization $\left(\mathrm{r}=0.512^{*}\right)$ in district Pulwama.

Table.1 Isolation of arbuscular mycorrhizal spores from rhizospheric soil of apple from Different locations of District Pulwama

\begin{tabular}{|l|c|c|c|c|c|}
\hline \multirow{2}{*}{ Locations } & \multicolumn{6}{|c|}{ Spore count per gram of soil (Identified Genera) } \\
\cline { 2 - 6 } & Acaulospora & Scutellospora & Gigaspora & Glomus & Unidentified Genera \\
\hline Rajpora & - & - & 1 & 2 & 4 \\
\hline Shadimarg & 2 & - & 3 & 3 & 4 \\
\hline Nikas & 1 & 2 & - & - & 4 \\
\hline Drubgam & - & 1 & 1 & 2 & 3 \\
\hline Shiekar & 2 & - & 1 & - & 5 \\
\hline Tikkin & 3 & - & - & 3 & 4 \\
\hline Sunsomil & - & - & 2 & 2 & 4 \\
\hline Pinglin & 3 & 2 & 1 & - & 6 \\
\hline Gungoo & - & 1 & - & 4 & 3 \\
\hline Puhoo & 3 & - & - & - & 5 \\
\hline
\end{tabular}


Table.2 Morphological features of isolated genera of AM fungi

\begin{tabular}{|l|c|c|c|c|c|}
\hline Genera & $\begin{array}{c}\text { Spore size } \\
(\boldsymbol{\mu m} \\
\text { diameter })\end{array}$ & $\begin{array}{c}\text { Spore } \\
\text { shape }\end{array}$ & $\begin{array}{c}\text { Spore } \\
\text { Colour }\end{array}$ & Spore wall & $\begin{array}{c}\text { Hyphal } \\
\text { colour }\end{array}$ \\
\hline Acaulospora & $115-170$ & $\begin{array}{c}\text { Globose to } \\
\text { sub globose }\end{array}$ & $\begin{array}{c}\text { Yellow } \\
\text { brown to } \\
\text { dark brown }\end{array}$ & $\begin{array}{c}\text { Three layered } \\
\text { (L1.L2 and L3) }\end{array}$ & $\begin{array}{c}\text { Grey } \\
\text { white }\end{array}$ \\
\hline Gigaspora & $200-300$ & $\begin{array}{c}\text { Globose to } \\
\text { sub globose }\end{array}$ & $\begin{array}{c}\text { White to } \\
\text { cream } \\
\text { usually a rose } \\
\text { pink tint. }\end{array}$ & $\begin{array}{c}\text { Bilayered } \\
\text { layered (L1 and } \\
\text { L2) }\end{array}$ & $\begin{array}{c}\text { Orange } \\
\text { brown }\end{array}$ \\
\hline Scutellospora & $100-170$ & $\begin{array}{c}\text { Sub globose } \\
\text { to ellipsoid } \\
\text { to oblong }\end{array}$ & $\begin{array}{c}\text { Cream to } \\
\text { yellow or } \\
\text { pale orange } \\
\text { brown to } \\
\text { dark orange } \\
\text { brown }\end{array}$ & $\begin{array}{c}\text { Bilayered spore } \\
\text { wall (L1 and } \\
\text { L2) }\end{array}$ & $\begin{array}{c}\text { Hyaline } \\
\text { to orange } \\
\text { white. }\end{array}$ \\
& $40-120$ & Globose to & $\begin{array}{c}\text { red brown to } \\
\text { ellipsoid } \\
\text { almost black } \\
\text { most are } \\
\text { yellow brown }\end{array}$ & $\begin{array}{c}\text { three layered } \\
\text { (L1,L2 and L3) }\end{array}$ & $\begin{array}{c}\text { Hyaline } \\
\text { to } \\
\text { yellowish. }\end{array}$ \\
\hline
\end{tabular}

Table.3 In vitro root colonization by AM fungal spores isolated from District Pulwama

\begin{tabular}{|c|c|c|}
\hline Locations & Genera & Root Colonization (\%) \\
\hline Rajpora & $\begin{array}{l}\text { Gigaspora sp. } \\
\text { Glomus sp. }\end{array}$ & $\begin{array}{l}68.23 \\
72.05\end{array}$ \\
\hline Shadimarg & $\begin{array}{l}\text { Acaulospora sp. } \\
\text { Gigaspora sp. } \\
\text { Glomus sp. }\end{array}$ & $\begin{array}{l}65.87 \\
70.03 \\
72.13\end{array}$ \\
\hline Nikas & $\begin{array}{l}\text { Scutellospora sp. } \\
\text { Acaulospora } \mathrm{sp} .\end{array}$ & $\begin{array}{l}69.09 \\
70.05\end{array}$ \\
\hline Drubgam & $\begin{array}{l}\text { Scutellospora sp. } \\
\text { Glomus sp. } \\
\text { Gigaspora } \mathrm{sp} .\end{array}$ & $\begin{array}{l}73.23 \\
76.67 \\
69.08 \\
\end{array}$ \\
\hline Shiekar & $\begin{array}{l}\text { Gigaspora sp. } \\
\text { Acaulospora sp. }\end{array}$ & $\begin{array}{l}73.56 \\
68.67\end{array}$ \\
\hline Tikkin & $\begin{array}{l}\text { Acaulospora sp. } \\
\text { Glomus sp. }\end{array}$ & $\begin{array}{l}72.13 \\
68.78\end{array}$ \\
\hline Sunsomil & $\begin{array}{l}\text { Gigaspora sp. } \\
\text { Glomus sp. }\end{array}$ & $\begin{array}{l}67.67 \\
79.55\end{array}$ \\
\hline Pinglin & $\begin{array}{l}\text { Acaulospora } \mathrm{sp} . \\
\text { Gigaspora } \mathrm{sp} . \\
\text { Scutellospora } \mathrm{sp} .\end{array}$ & $\begin{array}{l}79.56 \\
67.80 \\
65.87\end{array}$ \\
\hline Gungoo & $\begin{array}{l}\text { Scutellospora sp. } \\
\text { Glomus sp. }\end{array}$ & $\begin{array}{l}69.77 \\
79.78\end{array}$ \\
\hline Puhoo & Acaulospora sp. & 76.86 \\
\hline
\end{tabular}


Table.4 Mean soil phosphatase activity under field conditions of District Pulwama

\begin{tabular}{|l|c|}
\hline Villages & Phosphatase $(\boldsymbol{\mu g P N P} / \mathbf{g} / \mathbf{2 4 h r})$ \\
\hline Rajpura & 29.76 \\
\hline Shadimarg & 30.12 \\
\hline Nikas & 33.62 \\
\hline Drubgam & 31.78 \\
\hline Shiekar & 26.67 \\
\hline Tikkin & 33.08 \\
\hline Sunsomil & 29.78 \\
\hline Pinglin & 34.56 \\
\hline Gungoo & 32.78 \\
\hline Puhoo & 30.34 \\
\hline Mean & $\mathbf{3 1 . 2 4}$ \\
\hline CD(P $\leq \mathbf{0 . 0 5})$ & $\mathbf{1 . 7 0 9}$ \\
\hline CV & $\mathbf{3 . 1 3 3}$ \\
\hline
\end{tabular}

Table 5 Correlation between spore population and other studied parameters of District Pulwama

\begin{tabular}{|l|c|}
\hline Parameters & Spore population \\
\hline Spore population & 1 \\
\hline Organic carbon & $0.887^{* *}$ \\
\hline Available Nitrogen & $0.815^{*}$ \\
\hline Available Phosphorus & 0.797 \\
\hline Available Sulphur & 0.910 \\
\hline Available Potassium & $0.614^{*}$ \\
\hline Soil Phosphatase & 0.458 \\
\hline Root colonization & $0.512^{*}$ \\
\hline
\end{tabular}

* Correlation is significant at the 0.05 level; $* *$ Correlation is significant at the 0.01 level

Fig.1 Spores of the genus Acaulospora

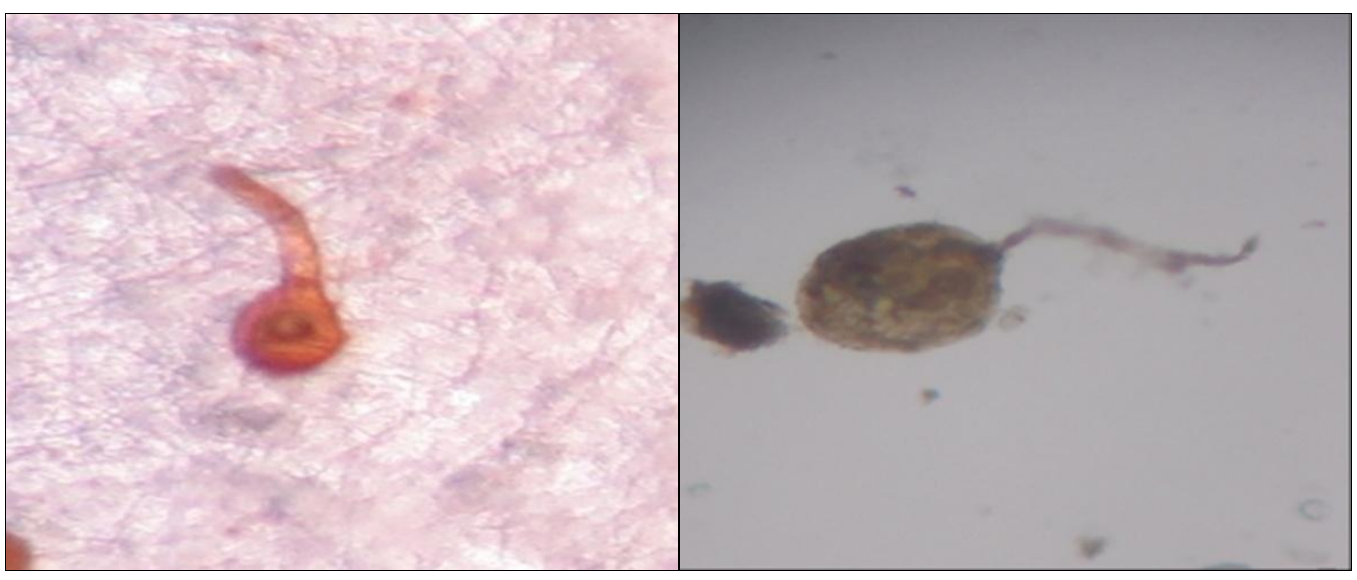


Fig.2 Spores of the genus Glomus

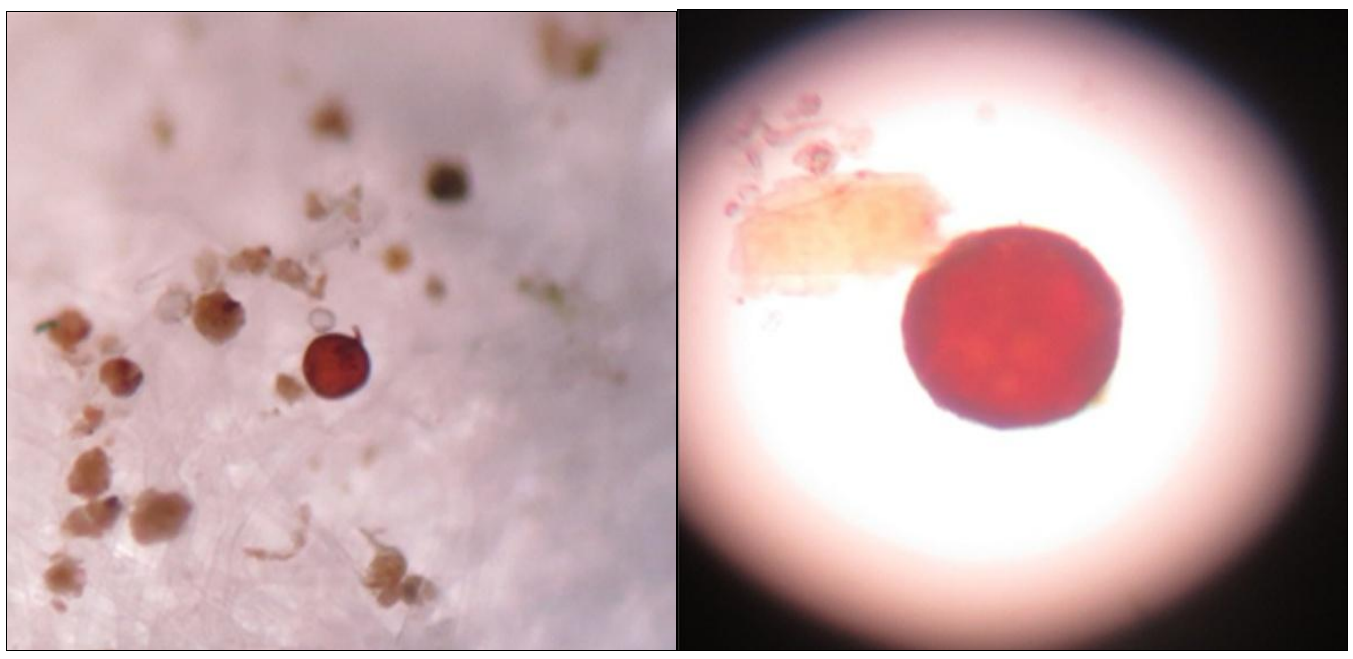

Fig.3 Spores of the genus Gigaspora

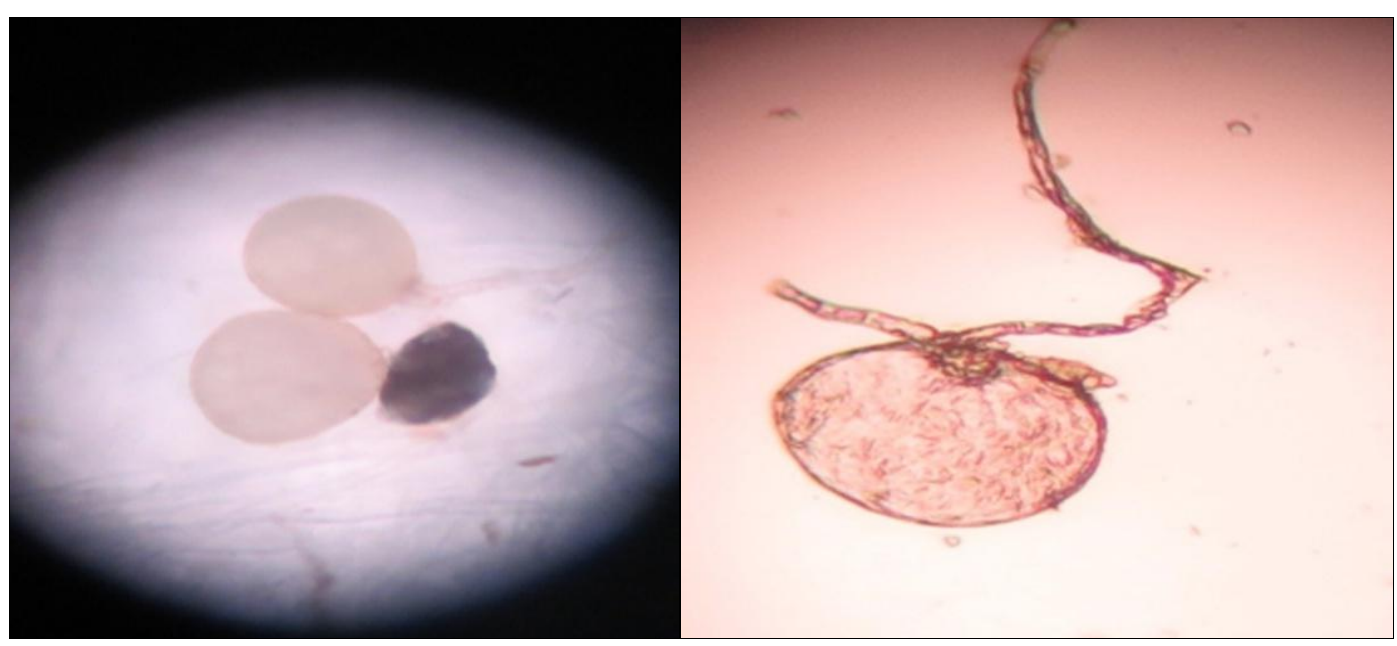

Fig.4 Spores of the genus Scutellospora

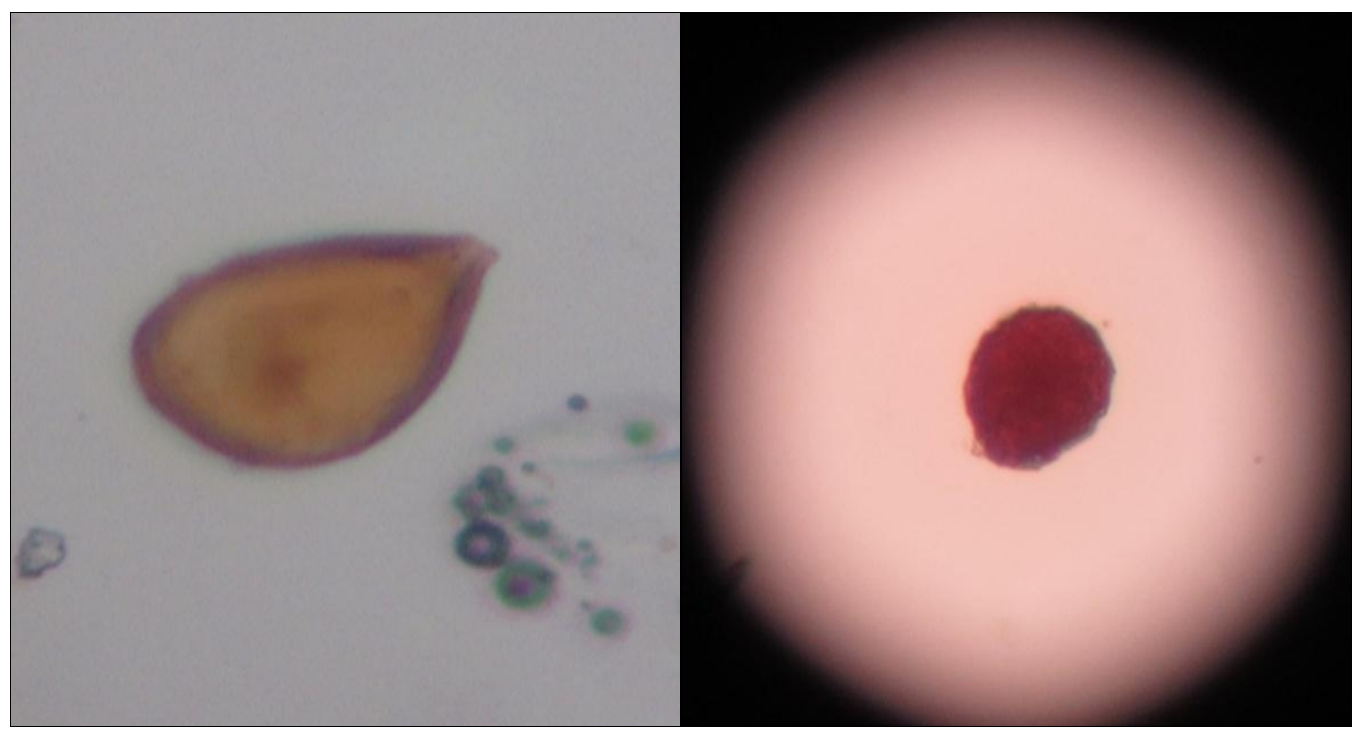


Fig.5 Root colonisation of the genus Acaulospora

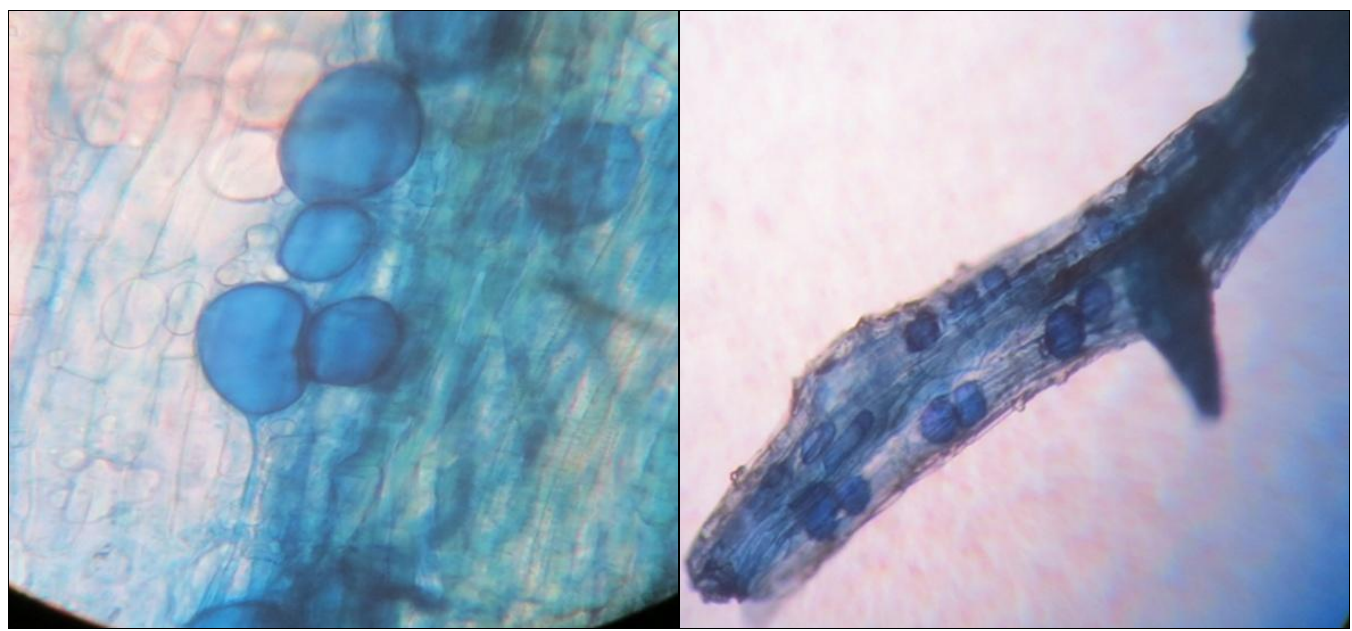

Fig.6 Root colonisation of the genus Scutellospora

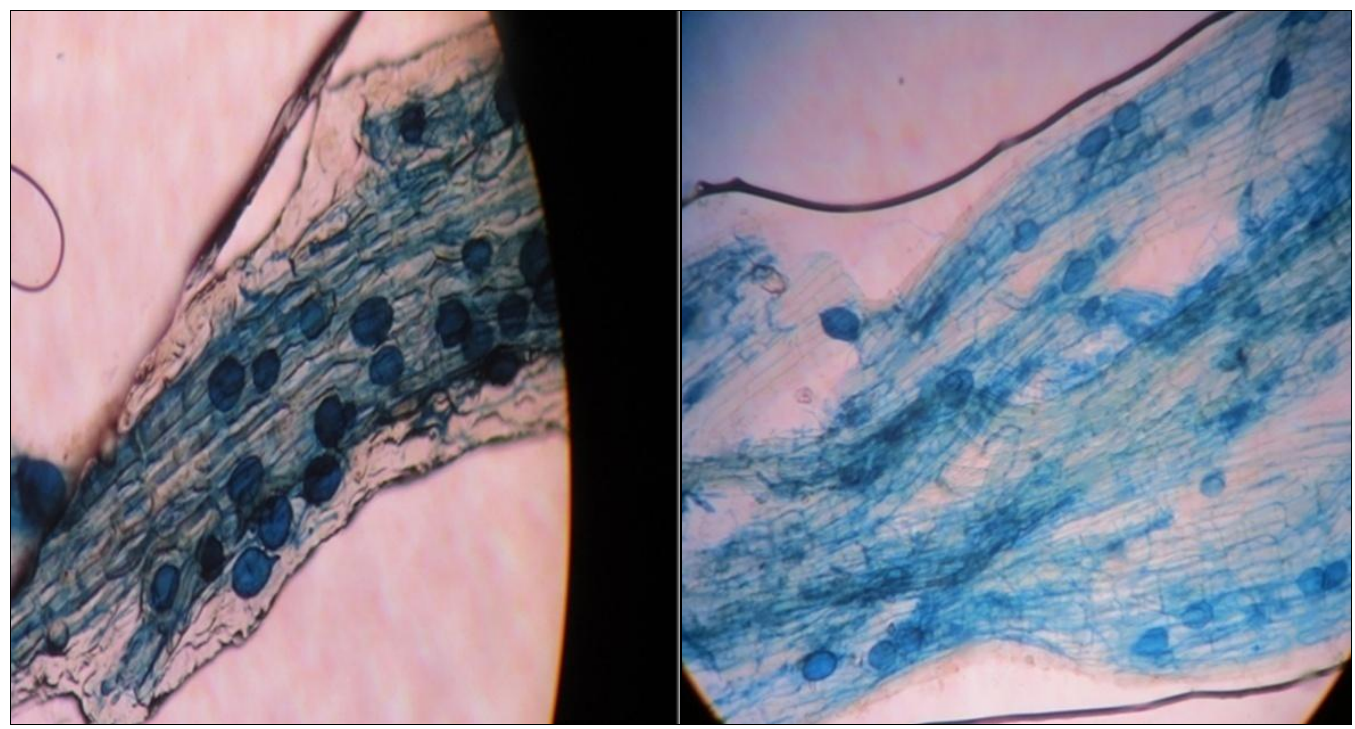

Fig.7 Root colonisation of the genus Glomus

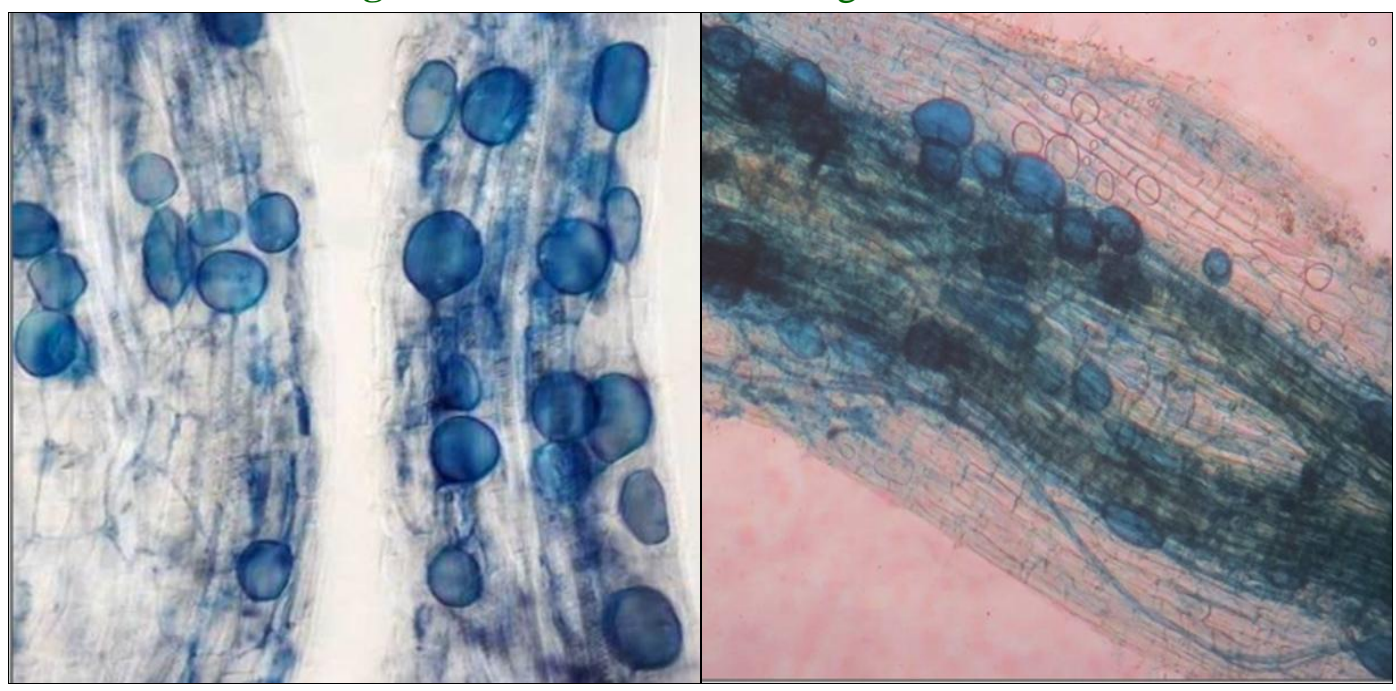


Fig.8 Root colonisation of the genus Gigaspora

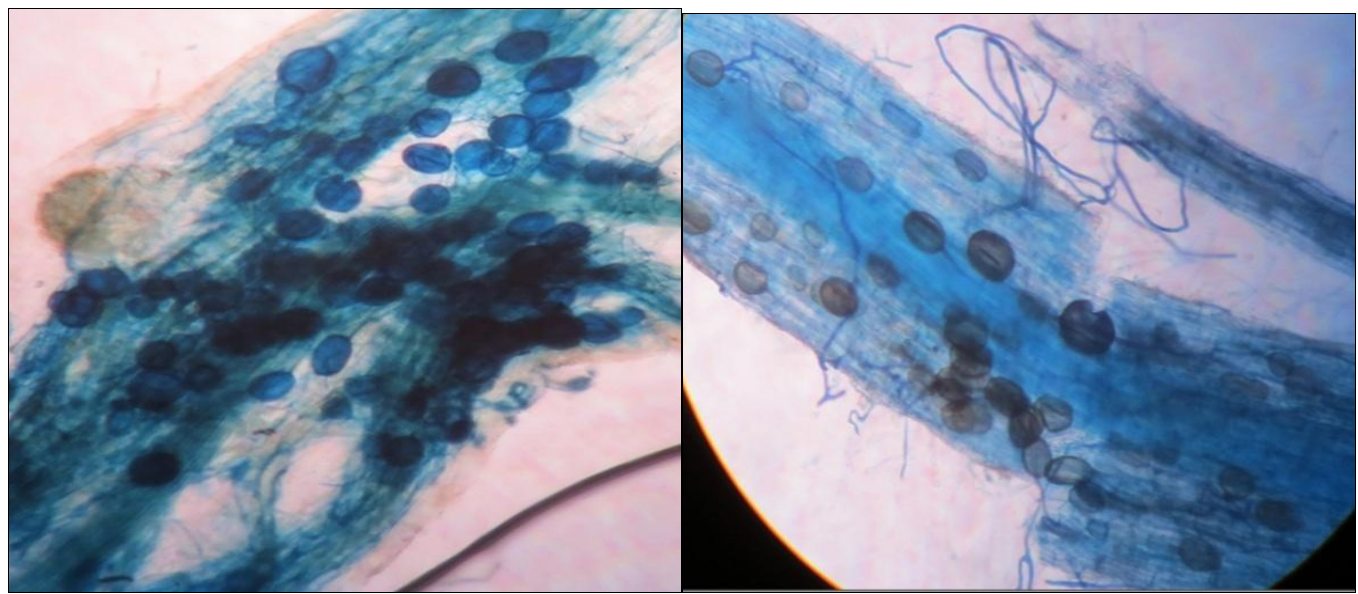

Pulwama with geographic coordinates of $33.87162^{\circ} \mathrm{N}, 74.8946^{\circ} \mathrm{E}$

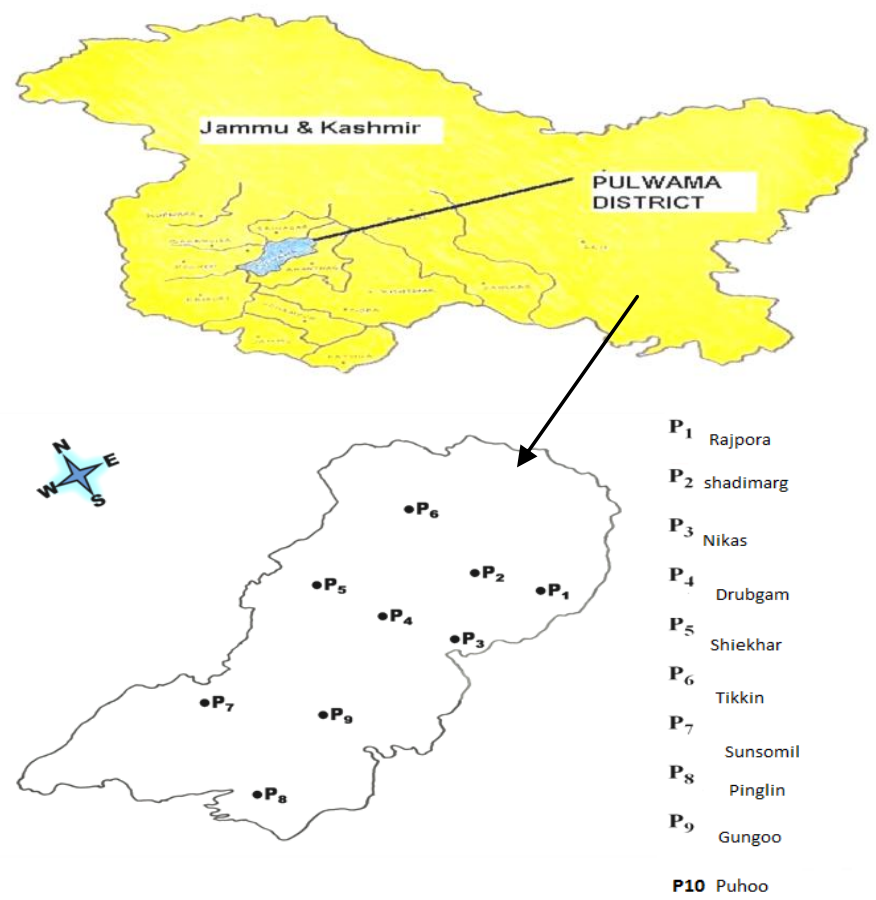

Kumar also found a significant positive correlation between mycorrhizal spores and colonization (Kumar et al., 2013).Yang et al., (2010) found a positive correlation between and mycorrhizal colonization and spores. These results are also supported by Li et al., (2009). The positive and significant correlation between AM spores and available nitrogen $\left(\mathrm{r}=0.815^{*}\right)$ was found which might be due to the fact that nitrogen and organic carbon are required by micro-organisms for their special requirements and as a result high nitrogen and organic carbon in the soil increased infection and population of AM fungi. Similar results were reported (Venkatrao et al., 1972). Since the climatic conditions of the study area fall under temperate zone which are conducive to the mycorrhizal development, it is possible that concentration of such propagules may be higher (Akhter, 2005). Moreover, influence of apple roots through their exudates cannot be ruled out which needs further studies. 


\section{Soil phosphatase activity}

Phosphatase activity of soils of District Pulwama was found to be 26.67 to 34.56 $\mu \mathrm{gPNP} / \mathrm{g} / 24 \mathrm{hr}$ with an average value of 31.24 $\mu \mathrm{gPNP} / \mathrm{g} / 24 \mathrm{hr} \quad$ (Table 5). Maximum phosphatase activity $(34.56 \mu \mathrm{gPNP} / \mathrm{g} / 24 \mathrm{hr})$ was recorded in Pinglin which was statistically at par with Nikas and Tikkin, however, significantly superior to other villages. The results are in conformity with the results of Eichler et al., (2004) who observed the phosphatase activity between 15.8 to 35.2 $\mu \mathrm{gPNP} / \mathrm{g} / 24 \mathrm{hr}$ in the soil. Ohm et al., also observed the phosphatase activity of 19 to 38 $\mu \mathrm{gPNP} / \mathrm{g} / 24 \mathrm{hr}$ (Ohm et al., 2013).

Soil acid phosphomonoesterase activity was higher at low available $\mathrm{P}$ content of soil than at high content which was supported by other findings (Speir and Cowling, 1991; Santruckova, 2004) as they found that higher enzymatic hydrolysis of organic P depended on the higher microbial $\mathrm{P}$ immobilisation but not on the higher mineralisation of organic $\mathrm{P}$ compound.

The reason could be that when available phosphorus is deficient in soil, soil biota increases the production of extracellular phosphatase to enhance the supply of inorganic $\mathrm{P}$ in soil. Relationships between soil $\mathrm{P}$ supply and phosphatase activities are regulated by negative feedback mechanis (Olander and Vitousek, 2000).

\section{Acknowledgement}

The authors are thankful to Sher e Kashmir University of Agricultural Sciences and Technology of Kashmir for providing laboratory facilities.

\section{References}

Akhter, F.2005. Studies on relationship between fruit yield and quality with soil and leaf nutrient content in apple orchards of Zangier block of district Baramulla
Kashmir. University of Kashmir Digital Repository.

Almeida, R.T. and Schenck, N.C.1990. A revision of the genus Sclerocystis (Glomaceae, Glomales) Mycologia.82: 703-714.

Anonymous.2016. Area and Production of main Fruits in Jammu and Kashmir State. Department of Horticulture, Government of Jammu and Kashmir, Srinagar, J\&K.

Beckjord, P.R., McIntosh, M.S., Hacskaylo, E. and Melhuish, J.H.1984..Inoculation of Loblolly Pine Seedlings at Planting with Basidiospores of Ectomycorrhizal Fungi in Chip Form. Research Note No. 324, Forest Service, North-Eastern Forest Experiment Station, Florida, USA. 25 Pp.

Bentivenga, S.P., Morton, J.B.1995. A monograph of the genus Gigaspora, incorporating developmental patterns of morphological characters. Mycologia. 87:720-732.

Burni, T., Iftikhar, S., Jabeen, $M$ and Zainab, S.B.2009. Diversity of VA (Vesicular Arbuscular) fungi in some weeds of cauliflower fields of Peshawar, Pakistan. Pak. J. Plant Sci. 15 (1): 59-67.

Chadha, K.L.1993. Horticultural crops Present status future thrusts. Souvenir HSI Golden Jubilee Symposium, Horticultural Research Changing Scenario, Bangalore, India. Pp. 1-3

Chesnin, L. and Yien, C.H. 1951. Turbidimetric determination of available sulphur. Proc. Soil Sci. Soc. Am.15:149-151.

Eichler, B., Caus, M., Schnug, E. and Köppen, D.2004.Soil acid and alkaline phosphatase in relation to crop species and fungal treatment. Landbauforsch. Volk. 54: 1-5.

Gerdemann, J.W., Nicolson, T.W.1963. Spores of mycorrhizal Endogone species extracted from soil by wet sieving and decanting method. Trans. Br. Mycol. Soc. 46:235-245.

Giovannetti, M., Mosse, B. 1980.evaluation of techniques for measuring vesicular arbuscular mycorrhizal infection in roots. New Phytol.84:489-509. 
Gomez,K.A and Gomez, A.A.1984. Statistical procedure for Agricultural Research An international Rice Research Institute Book. John Wiley and sons, 2nd edition 190.

Gosal, S.K., Sandhu, A., Gupta, R.P and Kaul, V.K.2003. Establishment and maintenance of vesicular arbuscular mycorrhiza on hode grass. Indian $J$. Microbiol. 43 (1): 53-54.

Greene, D.W, Manning, W.J., Cooley, D.R.1982.Effect of the ectomycorrhizal fungus Pisolithustinctorius and auxin rooting formulations on growth of 'Cortland' apple trees. Hortic. Sci. 17: 655- 656.

INVAM.2005.

website. http://invam.caf.wvu.Edu/fungi/taxonomy / classification.html.

Jackson, M.L.1973. Soil Chemical Analysis. Prentice Hall India, New Delhi, India. 498.

Kandula, K., Jones, E., Stewart, A. and Horner, J.2006. Colonisaton of apple roots by arbuscular mycorrhiza in specific apple replant disease affected soil. New Zealand Plant Prot. 59:92-96.

Koske, R.E. and Gemma, J.N.1990.VA mycorrhizae in strand vegetation of Hawaii: evidence for long-distance codispersal of plants and fungi. Am. J. Bot.77:466-474.

Koske, R.E.1987.Distribution of VA mycorrhizal fungi along a latitudinal temperature gradient. Mycologia. 79:5568.

Koske, R.E.1984.Spores of VAM fungi inside spores of VAM fungi. Mycologia. 76:853-862

Kumar, S., Chaudhuri, S., Maiti, S.K.2013. Soil dehydrogenase enzyme activity, in Natural and mine soil - a review. MiddleEast J. Sci. Res. 13 (7):898-906.

Li, L., Li, T., Zhang, Y. and Zhao, Z.2009. Molecular diversity of arbuscular mycorrhizal fungi and their distribution patterns related to host-plants and habitats in a hot and arid ecosystem, southwest China. FEMS Microbiol. Ecol. 71:418-
427.

Lipinski, W., Terelak, H. and Motowicka, T.2003. Suggestion for liming values of sulphatesulphur content in mineral soils for fertilization advisory needs. Soil Sci. Апnu. 54(3):79-84.

Makoi, J.H. and Nolakidema, P.A. 2008. Selected soil enzymes: Examples of their potential roles in the ecosystem. Afr. J. Biotechnol. 7(3):181-191.

Malik, M.A., Zargar, M.Y., and Baba Z.A.2016. Characterization of arbuscular mycorrhizal fungi in apple (Malus domestica Borkh) growing area in Kashmir Himalaya (India): A case study of Bandipora district. Afr. J. Microbiol. Res., 10(43), 1813-1821.

Morton, J.B. 1988.Taxonomy of VAM fungi, classification, nomenclature and identification. Mycotaxon. 32:267-324.

Morton, J.B. and Benny, G.L.1990. Revised classification of arbuscular mycorrhizal fungi (Zygomycetes): a new order, Glomales, two new suborders, Glomineae and Gigasporineae, and two new families, Acaulosporaceae and Gigasporaceae, with an emendation of Glomaceae. Mycotaxon. 37: $471-491$

Morton, J.B.2002. International Culture Collection of Arbuscular and VesicularArbuscular Mycorrhizal Fungi. West Virginia University.

Mridha, M., Dhar, P.2007.Biodiversity of Arbuscular Mycorrhizal colonization and spore population in different Agroforestry trees and crop species growing in Dianajpur Bangladesh. J. Forest. Res. 18(2):91-96.

Ohm, M., Paulsen, H.M., Eichler-Löbermann, B. and Rahmann, G.2013. Development of phosphatase and dehydrogenase activities in soils of annual cropland and permanent grassland in an organic farm. NJF Rep.9:123-124.

Olander, L.P. and Vitousek, P.M.2000. Regulation of soil phosphatase and chitinase activity by $\mathrm{N}$ and $\mathrm{P}$ availability. Biogeochemistry. 49:175-190.

Olsen, S.R., Cole, C.V., Watanabe, F.S., Dean, 
L.A.1954. Estimation of available phosphorus in soils by extraction with sodium bicarbonate. U.S. Dept. Agric. Circ. Pp.939.

Pande,M. and Tarafdar, J.F.2004.Arbuscular Mycorrhizal fungal diversity in Neem based Agroforestry Systems in Rajastan. Appl. Soil Ecol.26:233-241.

Phillips, J.M. and Hayman, D.S.1970. Improved procedures for clearing roots and staining parasitic and vesicular arbuscular mycorrhizal fungi for rapid assessment of infection. Trans. Br. Mycol. Soc.55:150161.

Riffaldi, R., Saviozzi, A., Levi-Minzi, R. and Cardelli, R. 2002.Biochemical properties of Mediterranean soil as affected by longterm crop management systems. Soil \& Tillage Research. 67: 109-114.

Santruckova, H., Vrba, J., Picek, T. and Kopacek, 2004. J. Soil biochemical activity and phosphorus transformations and losses from acidified forest soils. Soil Biol Biochem. 36:1569-1576.

Schenck, N.C. and Parez, Y.1990. Manual for the identification of VA mycorrhizal fungi INVAM, University of Florida, Gainesville USA.1- 283.

Schenck, N.C. and Smith, G.S.1982. Additional new and unreported species of mycorrhizal fungi (Endogonaceae) from Florida. Mycologia. 77:566- 574.

Sharma, D., Kapoor, R. and Bhaytnagar, A.R. 2009.Differential growth response of Curculigoorchoides to native AMF communities varying in number and fungal components. Euro. J. Soil Biol.45 (4):328-333.

Smith, S.E and Read, D.J.2008. Mycorrhizal Symbioses. Academic Press, London, U.K. Assessment of Mycorrhizal Frequency in the Roots of Fruit Plants
Using Different Dyes.

Speir, T.W. and Cowling, J.C. 1991.Phosphatse activities of pasture plants and soils: relationship with plant productivity and $\mathrm{P}$ fertility indices. Biol. Fertil Soils. 12:18919.

Stanford, S and English.1949. Use of the flame photometer in rapid soil tests of potassium and calcium. Agron. J. 41: 446-447.

Venkatrao, B.V., Bagyaraj, D.J and Rangaswamy, M.1972. Changes in physiological and microbial properties of red soils of Mysore as a result of heavy fertilization. Indian J. Agric. Sci. 42: 22629.

Walker, C., Vestberg, M., Demircik, F., Stockinger, H., Saito, M., Nishmura, I and Schubler, A.2007.Molecular phylogeny and new taxa in the Archaesporales (Gloremycota): Ambiospora feennicagen sp.nov, Ambisporaceae fam nov., and emendation of archaeospora and Archaesporaceae. Mycol. Res.111:137-153.

Walker, C. and Vestberg, M.1998. Synonymy amongst the arbuscular mycorrhizal fungi: Glomus claroideum, $G$. maculosum, $G$. multisubstensum, and $G$. fistulosum. Annals of Botany. 82: 601-612.

Walkley, A. and Black, I.A. 1934.An examination of the Degtjareff method for determining soil organic matter and a proposed modification of the chromic acid titration method. Soil Sci. 37:29-38.

Yang, R.Y., Zan, S.T., Tang, J.J., Chen, X and Zhang, Q.2010.Variation in community structure of arbuscular mycorrhizal fungi associated with a $\mathrm{Cu}$ tolerant plantElsholtzia splendens. Appl. Soil Ecol. 44:191-197.

\section{How to cite this article:}

Misbah Ajaz, Mohammad Yousuf Zargar and Jagana Chandra Sekhar. 2017. Isolation, Identification and Characterization of Arbuscular Mycorrhizal Fungi in Apple (Malus domestica Borkh) Growing Area of Kashmir Himalaya. Int.J.Curr.Microbiol.App.Sci. 6(8): 25-37. doi: https://doi.org/10.20546/ijcmas.2017.608.005 